\title{
Digestibility and clover proportion determine milk production when silages of different grass and clover species are fed to dairy cows
}

\author{
M. Johansen, ${ }^{* 1}$ K. Søegaard, $†$ P. Lund, ${ }^{*}$ and M. R. Weisbjerg* \\ *Department of Animal Science, and \\ †Department of Agroecology, AU Foulum, Aarhus University, 8830 Tjele, Denmark
}

\begin{abstract}
This study examined how silages of different grass and clover species affect dry matter (DM) intake, milk production, and eating behavior in dairy cows. The primary growth of perennial ryegrass (early and late harvested), festulolium, tall fescue, red clover, and white clover swards were cut, wilted, and ensiled without additives. Thirty-six Danish Holstein cows were fed ad libitum with total mixed rations containing $70 \%$ forage on DM basis in an incomplete Latin square design. The forage source was either 1 of the 6 pure silages or late perennial ryegrass silage mixed (50:50 on DM basis) with either red clover or white clover silage. Intake of DM, milk yield, and milk lactose concentration were higher, whereas milk fat and protein concentrations were lower when cows were fed clover compared with grass. No differences in DM intake and milk composition were detected between cows fed red clover and white clover, but white clover resulted in higher milk yield than red clover. Lower body weight, probably caused by lower rumen fill, in cows fed pure white clover compared with the other treatments indicated that intake was regulated physiologically instead of physically. Cows fed early perennial ryegrass, which had the highest silage organic matter digestibility (OMD), did not produce the expected amount of energy-corrected milk (ECM) compared with the other treatments based on the amount of $\mathrm{OM}$ digested in the gastrointestinal tract, but the reason was unclear. Across all other grass species, ECM was related to OMD. Inclusion of $50 \%$ clover in the diet increased ECM with $2.3 \mathrm{~kg} / \mathrm{d}$, and the response to OMD was comparable to the response for the grass silages. In situ fiber degradation profile parameters indicated that fiber in festulolium differed compared with fiber in the other grass species and resembled fiber in clover. Drinking and eating behavior differed markedly in cows fed pure white clover
\end{abstract}

Received June 27, 2017.

Accepted July 25, 2017.

${ }^{1}$ Corresponding author: marianne.johansen@anis.au.dk compared with the other treatments. Water intake per drinking bout was comparable among treatments, but cows fed pure white clover had higher drinking bout duration and reduced drinking rate. Additionally, meal size was smaller for cows fed pure white clover compared with the other treatments, for which meal size was similar. In conclusion, differences in ECM between different grass species can be explained by differences in OMD, and at a given OMD level inclusion of clover in the diet increased ECM.

Key words: legume, organic matter digestibility, eating behavior, drinking behavior, feces score

\section{INTRODUCTION}

Forages with high field yields are important to sustain a profitable milk production system; simultaneously, dairy cows require forages that are highly digestible to provide a high milk yield. Grass-clover silages often constitute a major part of the feed rations for dairy cows, and thus a stable production of high-quality herbage is essential. Yield and quality of different grass and legume species are highly dependent on geographical location, weather conditions, and farming management; therefore, selection of species is important for an optimal forage production. Alstrup et al. (2016) found that grass-clover silages of different cuts had similar values for milk production at comparable digestibility. Recently, a meta-analysis showed that milk production, in cows fed different grass species, is comparable provided that OM digestibility is similar (Johansen et al., 2017). However, few studies have compared different grass species. Furthermore, it is well documented that DMI and milk production generally are higher in cows fed legume-based diets compared with grass-based diets (Steinshamn, 2010; Johansen et al., 2017), as legumes contain less fiber than grasses and have a higher degradation rate of fiber in the rumen due to differences between legumes and grasses in the physical position of lignin (Buxton and Redfearn, 1997). However, effects of clover versus grass on eating behavior are scarce in the literature. Different grass and clover species vary in 
morphology, resulting in widely different leaf-to-stem ratios, which could affect eating behavior and milk production potential of single species.

The objective of the current study was to investigate how silages of the most relevant grass and clover species under Danish conditions affect DMI, eating behavior, and milk production in dairy cows. Our hypotheses were that (1) at similar silage OM digestibility, intake of clover silage is higher than intake of grass silage, resulting in a higher milk production and (2) milk production in cows fed silages of different grass or clover species reflects silage OM digestibility.

\section{MATERIALS AND METHODS}

The current experiment complied with the guidelines of Danish Ministry of Environment and Food (2014) Law No. 474 (May 15, 2014) concerning animal experimentation and care of animals under study.

\section{Fields and Harvest}

In the beginning of April 2014, fields with pure perennial ryegrass (Lolium perenne L. 'Calvano 1'), festulolium (Festulolium braunii K.A 'Perun'), tall fescue (Festuca arundinacea Schreb. 'Tower'), red clover (Trifolium pratense L. 'Suez'), and white clover (Trifolium repens L. 'Silvester') were established at AU Foulum $\left(56^{\circ} 29^{\prime} \mathrm{N}, 9^{\circ} 35^{\prime} \mathrm{E}\right)$, Tjele, Aarhus University. These species were selected because perennial ryegrass is the dominating grass species in the oceanic climate of Europe, including Denmark; festulolium and tall fescue have been more common in Danish agriculture the last decade due to some advantages of cultivation compared with perennial ryegrass, and red clover and white clover are the major legume species in grass and pasture fields in Europe. Barley (Hordeum vulgare L. 'Columbus') was established as cover crop, with an amount of 110 $\mathrm{kg} / \mathrm{ha}$, and perennial ryegrass, festulolium, tall fescue, red clover, and white clover were sown with an amount of $21,24,36,6.3$, and $6.2 \mathrm{~kg} / \mathrm{ha}$, respectively. The cover crop was harvested in the middle of July, as whole crop on the clover fields, and in the beginning of August, at maturity on the grass fields. All fields were cut in the autumn 2014 to prepare the fields for winter. Before seeding, the fields received $25 \mathrm{t}$ of liquid manure per hectare, and $\mathrm{N}$ and $\mathrm{S}$ liquid inorganic fertilizer was supplied as needed. After harvest of the cover crop, the fields with festulolium and tall fescue received 20, 3, 12, and $5 \mathrm{~kg}$ of liquid inorganic $\mathrm{N}, \mathrm{P}, \mathrm{K}$, and $\mathrm{S}$, respectively, to maintain growth. In the middle of March 2015, the grass fields received $118 \mathrm{~kg}$ of N, $16 \mathrm{~kg}$ of $\mathrm{P}, 47 \mathrm{~kg}$ of $\mathrm{K}$, and $16 \mathrm{~kg}$ of $\mathrm{S}$ per hectare, and the clover fields received $116 \mathrm{~kg}$ of $\mathrm{K} / \mathrm{ha}$ allocated as liquid inorganic fertilizer. The primary growth of all species was mown in 2015 with a disc mower conditioner set to $7 \mathrm{~cm}$ stubble height and wilted on broad swaths to achieve a DM concentration of approximately $350 \mathrm{~g} / \mathrm{kg}$. The plan was to mow perennial ryegrass at 2 time points to obtain variation in OM digestibility, and the aim was that OM digestibility of tall fescue and festulolium should be within the range of the 2 perennial ryegrass cuts. Tall fescue, festulolium, and half of the perennial ryegrass (early perennial ryegrass) were mown May 21 and wilted for $3 \mathrm{~d}$ because of rain $(3.2 \mathrm{~mm})$ in the middle of the wilting period. The remaining perennial ryegrass (late perennial ryegrass), red clover, and white clover were all mown June 3 and wilted for $2 \mathrm{~d}$. The weed contamination was estimated visually to be below $2 \%$ in all fields. The developmental stage (Skinner and Moore, 2007) at harvest was elongation stage with 1,2 , and 3 nodes noticeable or visible for tall fescue, early perennial ryegrass, and festulolium, respectively, reproductive stage with visible spikelets for late perennial ryegrass, and late vegetative stage for red clover. White clover was in a vegetative stage without buds. After wilting, the crops were raked and chopped with a theoretical length of $15 \mathrm{~mm}$. The chopped crops were unloaded on a clean concrete area and mixed within crop to ensure homogeneity before baling in a stationary round baler (Orkel MP 2000, Orkel A/S, Fannrem, Norway). The bales were wrapped with 12 layers of plastic and ensiled without additives.

Prior to mowing, 5 spots $(30 \times 30 \mathrm{~cm})$ were randomly selected in each field, cut with shears to $7 \mathrm{~cm}$ stubble height, and pooled within species. To determine the leaf-to-stem ratio on DM basis, leaves (leaf blade and petiole) and stems (leaf sheath, stem, and flower) were separated by hand and dried for $48 \mathrm{~h}$ at $60^{\circ} \mathrm{C}$.

\section{Animals, Feeding, Housing, and Sampling}

Thirty-six Danish Holstein cows, 12 primiparous and 24 multiparous, were used for the experiment. The primiparous cows were $59 \pm 12$ (mean $\pm \mathrm{SD}$ ) DIM and the multiparous cows were $95 \pm 64$ DIM at the beginning of the experiment. All cows were fed ad libitum with a TMR based on $70 \%$ forage (DM basis), divided into 2 equal daily meals fed at 0800 and $1600 \mathrm{~h}$. The amount fed was adjusted daily to achieve 7 to $10 \%$ leftovers, but a minimum of $3 \mathrm{~kg}$. The only difference between treatments (Table 1) was the forage source, which was silage of either (1) early perennial ryegrass (EPR), (2) festulolium (FEST), (3) tall fescue (TF), (4) late perennial ryegrass (LPR), (5) 50\% red clover:50\% late perennial ryegrass (RC-LPR), (6) 50\% white clover:50 $\%$ late perennial ryegrass (WC-LPR), (7) red clover (RC), or (8) white clover (WC). The TMR were mixed 
daily before the morning feeding for 12 min in a Cormall auger mixer (Cormall A/S, Sønderborg, Denmark). The concentrate part consisted mainly of soybean meal and rolled wheat (Table 1) to reduce the amount of fiber originating from the concentrate. The LPR ration was adjusted with urea to reach a $\mathrm{CP}$ concentration of 160 $\mathrm{g} / \mathrm{kg}$ of DM. Titanium oxide $\left(\mathrm{TiO}_{2}\right)$ was included in the TMR as external marker to estimate fecal output.

Multiparous cows were blocked according to DIM and randomly assigned to 1 of the 8 dietary treatments in an $8 \times 8$ incomplete Latin square design with 4 periods. The 8 primiparous cows latest in lactation were randomly assigned to 1 of the 8 dietary treatments in an $8 \times 8$ incomplete Latin square design, similar to the multiparous cows, whereas the 4 primiparous cows earliest in lactation were randomly assigned to 1 of the 4 pure grass treatments (treatment 1-4) in a 4 $\times 4$ Latin square design. Each period lasted $21 \mathrm{~d}$. The experimental design resulted in 20 observations for the 4 grass treatments (treatment 1-4) and 16 observations for the 4 treatments including clover (treatment 5-8).

The cows were housed in a loose-housing system with concrete floor and cubicles with mattresses and sawdust as bedding in 2 groups according to parity (primiparous and multiparous). During the whole experiment, each cow had access to its own feeding trough, where an electronic ear tag controlled opening of the gate. One drinking trough per 6 cows was available for ad libitum intake of water, and all cows had access to all drinking troughs within group. The water troughs were filled up with approximately $36 \mathrm{~L}$ between visits. Feed and water intake along with number and duration of visits were measured automatically with the Insentec RIC system (Insentec, Marknesse, the Netherlands). The cows were milked twice daily at 0545 and $1645 \mathrm{~h}$ in a milking parlor. Milk yield was registered daily and milk samples were taken over $3 \mathrm{~d}$ (6 milkings) in the last week of each period and analyzed for fat, protein, and lactose monohydrate (Eurofins Steins Laboratorium, Vejen, Denmark). In the milking parlor exit, a platform scale was installed and live weight of the cows was measured automatically twice a day.

Six subsamples of feces $(350 \mathrm{~mL})$ were collected during the last $4 \mathrm{~d}$ of each period (d 18-20 at $1400 \mathrm{~h}$ and d 19-21 at $0800 \mathrm{~h}$ ) and frozen immediately after collection. At the end of the experimental period, fecal samples were thawed and pooled within cow and period. Feces consistency was scored on a 5-point (1-5; 1 is loose and 5 is firm) visual observation scale, using half points, before drying at $60^{\circ} \mathrm{C}$ for $72 \mathrm{~h}$ for $\mathrm{DM}$ determination and chemical analysis.

Each silage bale, when opened, was sampled by taking 5 to 10 subsamples randomly with the hand at different places in the bale to make a representative sample; a subsample was used for DM determination and another subsample was pooled within period. Samples of soybean meal and rolled wheat were taken once a week and pooled within period. Before drying and chemical analyses, period 1 and 2 and period 3 and 4 were pooled for both silages and concentrates. Furthermore, a silage sample pooled over all 4 periods was used to analyze carbohydrate fractions and for in situ studies of NDF and CP degradation. Samples of the TMR were taken daily the last $4 \mathrm{~d}$ of each period and DM concentration was determined and used to calculate DMI. A pooled sample within period was dried $\left(60^{\circ} \mathrm{C}\right)$ and used for chemical analyses.

\section{Chemical Analyses}

Samples for chemical analyses were ground to 1 mm (ZM 200 mill, Retsch GmbH, Haan, Germany). Ash concentration was determined in all samples by combustion at $525^{\circ} \mathrm{C}$ for $6 \mathrm{~h}$. Nitrogen was determined using a Vario MAX CN (Elementar Analysesysteme GmbH, Hanau, Germany) following the Dumas method (Hansen, 1989) and multiplied by 6.25 to determine CP. Following the Ankom procedures (Ankom, 2016), $\mathrm{NDF}, \mathrm{ADF}$, and ADL were determined sequentially according to Mertens (2002) using heat-stable amylase for the NDF step; values were corrected for ash using the ADL ash residue.

Titanium oxide in TMR and fecal samples was measured by digestion of samples with sulfuric acid and measuring of absorbance after addition of hydrogen peroxide (Myers et al., 2004). In feedstuffs, crude fat was analyzed after $\mathrm{HCl}$ hydrolysis and petroleum ether extraction (Stoldt, 1952) using a Soxtec system (Foss Analytical, Hillerød, Denmark). Total sugar was determined by the Luff-Schoorl method (European Community, 2012, 71/250/EEC). Soluble N in silages was determined by one-hour extraction $\left(39^{\circ} \mathrm{C}\right)$ in a borate-phosphate buffer (pH 6.75; Åkerlind et al., 2011). Silage samples were incubated in rumen fluid for $48 \mathrm{~h}$, followed by incubation in a pepsin- $\mathrm{HCl}$ solution according to Tilley and Terry (1963), and residues were combusted to determine in vitro OM digestibility (\% of $\mathrm{OM}$ ). Silage in vivo OM digestibility (OMD; $\%$ of $\mathrm{OM})$ was calculated as $4.10+0.959 \times$ in vitro $\mathrm{OM}$ digestibility (Møller et al., 1989; Åkerlind et al., 2011). In concentrate samples, the enzymatic digestibility of OM (\% of OM) was determined and OMD was calculated as $5.38+0.867 \times$ enzymatic digestibility of $\mathrm{OM}$ (Weisbjerg and Hvelplund, 1993; Åkerlind et al., 2011).

To measure silage $\mathrm{pH}$ and fermentation products, extracts were prepared by blending $100 \mathrm{~g}$ of chopped silage with $1 \mathrm{~L}$ of water, followed by centrifugation $\left(2,300 \times g, 20 \mathrm{~min}, 10^{\circ} \mathrm{C}\right)$. The $\mathrm{pH}$ was measured in 
JOHANSEN ET AL.

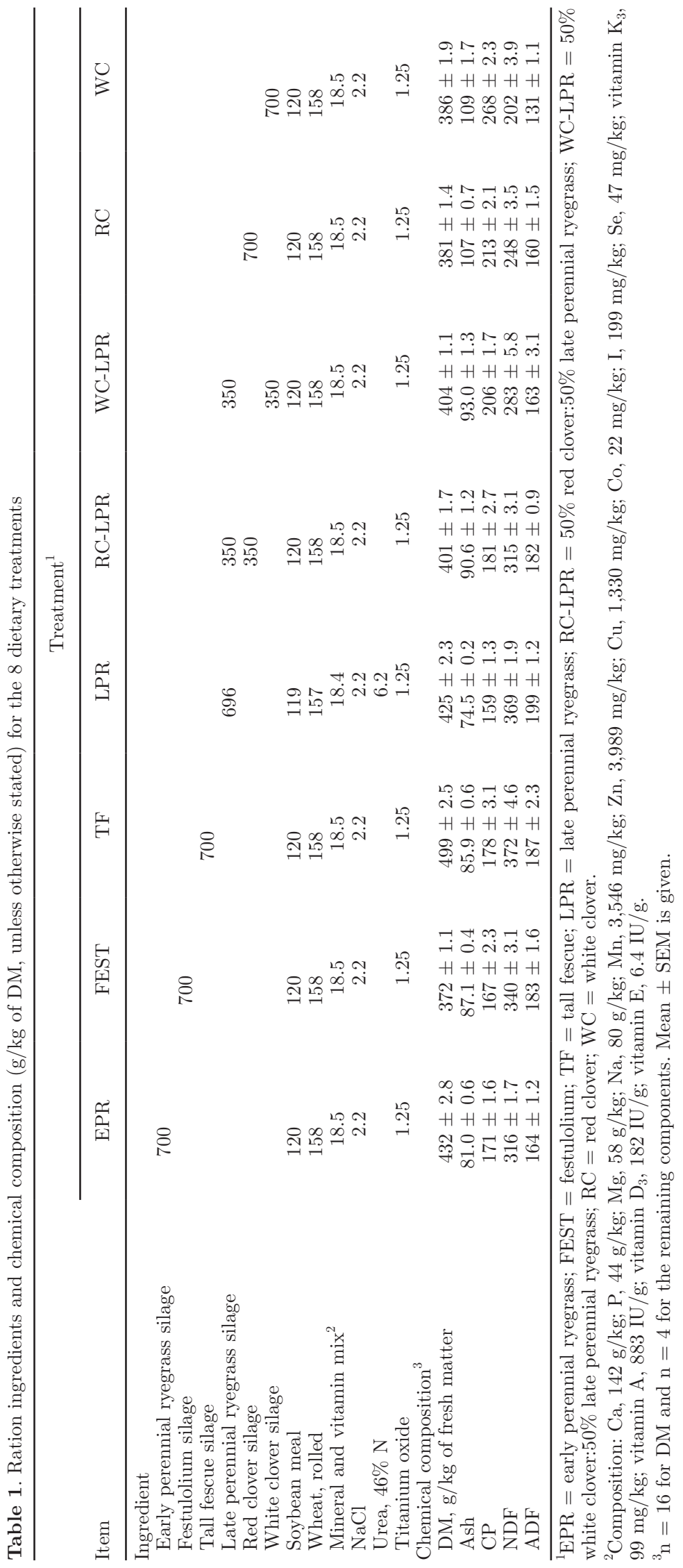


the supernatant. In silage extracts stabilized with $5 \%$ meta-phosphoric acid, VFA was analyzed by GC according to Kristensen et al. (1996). Ammonia N was analyzed using a kit based on glutamate dehydrogenase (AM 1015; Randox Laboratories Ltd., Crumlin, UK) and a Cobas Mira auto-analyzer (Triolab A/S, Brøndby, Denmark). Glucose was analyzed using an YSI 2900 Biochemistry Analyzer (YSI Inc., Yellow Springs, OH) and membrane-immobilized substrate specific oxidases. Alcohols and alcohol esters were analyzed by headspace GC-MS (Kristensen et al., 2010). In unstabilized silage extracts, DL-lactate was analyzed by GC-MS (Kristensen et al., 2010).

In silage samples pooled over all 4 periods, watersoluble carbohydrates were determined colorimetrically using the phenol-sulfuric acid assay (DuBois et al., 1956). Starch was analyzed according to the acetate buffer method described by Hall (2009), with the modifications that samples were incubated at $50^{\circ} \mathrm{C}$ instead of $60^{\circ} \mathrm{C}, 3.0 \mathrm{~mL}$ of glucose oxidase-peroxidase reagent was used instead of $2.5 \mathrm{~mL}$, and the last incubation was done at $50^{\circ} \mathrm{C}$ for $20 \mathrm{~min}$. Neutral detergent soluble fiber (NDSF) was determined both by extracting samples in $80 \%$ ethanol for $4 \mathrm{~h}$ at $20^{\circ} \mathrm{C}$ and by extracting samples in water for $1 \mathrm{~h}$ at $40^{\circ} \mathrm{C}$. In the ethanol or water insoluble residues, OM (IROM), and CP (IRCP) were determined and NDSF was calculated as IROM IRCP - NDF - starch (Hall et al., 1999). Silage samples [1.5 mm milling in Dacron (TP Filter, Upplands Väsby, Sweden) bags with $12 \mu \mathrm{m}$ pore size] were incubated in the rumen of dry cows fed at maintenance for 288 $\mathrm{h}$ and indigestible NDF (iNDF) was determined as the remaining NDF residue (Åkerlind et al., 2011). To determine in situ rumen degradation kinetics of $\mathrm{CP}$ and NDF, silage samples $(1.5 \mathrm{~mm}$ milling in Dacron bags with $38 \mu \mathrm{m}$ pore size) were incubated for $0,2,4,8,16$, 24,48 , and $96 \mathrm{~h}$, and further for $168 \mathrm{~h}$ for NDF in the rumen of dry cows fed at maintenance. Degradation profile parameters for $\mathrm{CP}$ were estimated according to the equation of Ørskov and McDonald (1979) and corrected for particle loss, estimated as the difference between $0 \mathrm{~h}$ solubility and solubility over filter paper (Hvelplund and Weisbjerg, 2000). Degradation profile parameters and lag time for NDF were estimated according to McDonald (1981) without the soluble fraction, as NDF is insoluble per definition, and the values used for parameter estimation were corrected for possible initial particle loss by relating the NDF residues to the NDF residue at $0 \mathrm{~h}$ of incubation, where bags were only washed. Disappearance of $\mathrm{CP}$ in the gastrointestinal tract was estimated in situ using the mobile bag technique described by Hvelplund et al. (1992), where silage samples (1.5 mm milling in nylon bags with $11 \mu \mathrm{m}$ pore size) were incubated for $16 \mathrm{~h}$ in the rumen of dry cows fed at maintenance, followed by incubation in a pepsin- $\mathrm{HCl}$ solution ( $\mathrm{pH} 2.4)$. Finally, the bags were inserted into the small intestine through the duodenal cannula of lactating cows and collected in feces. After washing, residues of both rumen and mobile bag incubations were transferred to $\mathrm{N}$-free filter paper, and $\mathrm{N}$ residues were measured quantitatively using the Kjeldahl procedure.

\section{Calculations}

Energy-corrected milk yield $(3.14 \mathrm{MJ} / \mathrm{kg})$ was calculated according to Sjaunja et al. (1991) using the formula $\mathrm{ECM}=0.01 \times$ milk yield $(\mathrm{kg})+12.2 \times$ milk fat $(\mathrm{kg})+7.7 \times$ milk protein $(\mathrm{kg})+5.3 \times$ milk lactose $(\mathrm{kg})$, where lactose was measured as lactose monohydrate and averaged over the last $3 \mathrm{~d}$ in each period. Dry matter intake was averaged over the last $4 \mathrm{~d}$ in each period. Titanium oxide was used as digestion marker and concentrations in TMR and feces were used to calculate fecal DM output and apparent total-tract digestibility of nutrients. Supply of $\mathrm{NE}_{\mathrm{L}}$ was calculated on individual level according to the Nordic feed evaluation system (NorFor) described by Volden and Nielsen (2011). Live weight of cows was averaged over the last $10 \mathrm{~d}$ of each period, but the last $5 \mathrm{~d}$ in period 3 were discarded, as the weight was unstable due to freezing weather.

In eating behavior data, initiation of a new meal was defined if the time between termination of one visit to onset of a new visit in the feeding trough was above 8 min (Dürst et al., 1993). Initiation of a new drinking bout was defined if the time between termination of one visit to onset of a new visit to a drinking trough was above 4 min (Dado and Allen, 1994). Eating and drinking duration, both total and for each meal and drinking bout, was equal to the time the gate to the feeding or drinking trough was opened.

\section{Statistical Analyses}

Statistical analyses were conducted in R 3.3.2 ( $\mathrm{R}$ Core Team, 2016). The effect of treatment on the various animal responses was analyzed with the following linear mixed model fitted with REML and the lmer function from the lme4 package (Bates et al., 2015):

$$
Y_{t l p d c}=\mu+\alpha_{t}+\beta_{l}+\gamma_{p}+\delta d+(\beta \gamma)_{l p}+A_{c}+E_{t l p d c},
$$

where $Y_{t l p d c}$ is the dependent response variable, $\mu$ is the overall mean, $\alpha$ is the fixed effect of treatment $(t=$ EPR, FEST, TF, LPR, RC-LPR, WC-LPR, RC, WR), 
$\beta$ is the fixed effect of parity ( $l=$ primiparous, multiparous), $\gamma$ is the fixed effect of period ( $p=1$ to 4 ), $\delta$ is the regression coefficient for DIM $d,(\beta \gamma)_{l p}$ is the interaction between parity and period, $A$ is the random effect of cow ( $c=1$ to 36$)$, and $E_{t l p d c}$ is the random residual error assumed to be independent with constant variance and normally distributed. The remaining 2 -way interactions were tested as well, but none were significant or improved the model. One cow in 1 period was discarded in the analysis because of a feeding mistake.

Least squares means (LSM) and standard error of mean, obtained using the lsmeans package (Lenth, 2016), are presented in the tables. Differences between LSM were evaluated using Tukey's method for comparing a family of 8 estimates. The contrast function was used to test the general effect of grass against clover (EPR, FEST, TF, and LPR vs. RC and WC), the general effect of red clover against white clover (RC-LPR and RC vs. WC-LPR and WC), and linear and quadratic effects of increasing the proportion of red clover and white clover, respectively, using LPR as the treatment without clover. Some response variables related to water intake and eating and drinking behavior were $\log _{10}$ or inverse transformed to obtain variance homogeneity and normality of residuals. For these variables, the transformed data with the statistics are presented in the table along with the back-transformed LSM. Statistical significance was regarded by $P$-values $\leq 0.05$ and tendencies were considered by $P$-values $\leq 0.10$.

\section{RESULTS}

\section{Silages and TMR}

Table 2 shows the chemical composition of used feedstuffs. Silage DM concentration ranged from $295 \mathrm{~g} / \mathrm{kg}$ in festulolium silage to $414 \mathrm{~g} / \mathrm{kg}$ in tall fescue silage. The clover silages generally had higher ash and CP concentrations and a lower NDF concentration compared with the grass silages. All silages reached a low $\mathrm{pH}$ (4.16-4.45) during ensiling, but the concentration of lactate was higher in clover silages than in grass silages (117-133 vs. $59.7-79.4 \mathrm{~g} / \mathrm{kg}$ of DM). For the remaining fermentation products, no general differences between grass and clover silages were observed. Red clover silage had lower concentrations of soluble $\mathrm{N}$ and ammonia $\mathrm{N}$ as a proportion of total $\mathrm{N}$ compared with the other silages ( 49.3 vs. $61.8-70.7 \%$ and 6.80 vs. $7.40-8.27 \%$, respectively). The postponed harvest of perennial ryegrass resulted in lower ash, $\mathrm{CP}$, and crude fat concentrations and a higher NDF concentration. The concentration of NDSF was higher in clover silages compared with grass silages when extracted with both water and ethanol
(Table 3). The iNDF as proportion of NDF was higher in clover silages compared with grass silages (18.2-23.6 vs. $7.74-11.9 \%$ ), which also was evident from the rumen degradable fraction of NDF being lower in clover silages than in grass silages. The degradation rate of the rumen-degradable fraction was higher in the clover silages than in the grass silages for both NDF and CP (Table 3). Silage OMD varied from $73.9 \%$ in tall fescue silage to $83.4 \%$ in early perennial ryegrass silage (Table 2 ), and OMD in the clover silages was within the range covered by the grass silages. Variation in chemical composition between TMR (Table 1) reflected the variation in chemical composition between silages, except $\mathrm{CP}$ in LPR, as we added urea to this ration to achieve a CP concentration of $160 \mathrm{~g} / \mathrm{kg}$ of DM, which was obtained (159 $\mathrm{g}$ of $\mathrm{CP} / \mathrm{kg}$ of DM; Table1).

\section{Intake and Weight}

Intake of DM varied from 18.8 to $21.7 \mathrm{~kg} / \mathrm{d}$ and was higher in cows fed clover than in cows fed grass $(P<$ 0.01 ), with no difference in DMI between cows fed red clover or white clover $(P=0.23$; Table 4$)$. The treatments EPR and FEST resulted in higher DMI than TF and LPR $(P<0.05)$. The DMI increased linearly when increasing the red clover proportion, whereas increasing the white clover proportion resulted in a quadratic effect, as DMI was similar for WC-LPR and WC. Nutrient intake reflected DMI and chemical composition of the TMR. Cows on the WC treatment were on average $16 \mathrm{~kg}$ lighter than cows on the other treatments $(P<$ 0.05; Table 4).

\section{Milk Yield and Composition}

Cows fed clover had a higher milk yield than cows fed grass (33.8 vs. $29.4 \mathrm{~kg} / \mathrm{d} ; P<0.01$ ), and cows fed white clover had a higher milk yield than cows fed red clover (33.7 vs. $32.2 \mathrm{~kg} / \mathrm{d} ; P<0.01$; Table 4$)$. The FEST treatment resulted in higher milk yield than TF and LPR. Milk fat and milk protein concentrations were lower (41.8 vs. 45.9 and 34.1 vs. $36.0 \mathrm{~g} / \mathrm{kg}$, respectively; $P<0.01$ ), whereas milk lactose concentration was higher $(48.4$ vs. $47.1 \mathrm{~g} / \mathrm{kg} ; P<0.01)$ when cows were fed clover compared with grass. Milk composition did not differ between cows fed red clover and white clover, but increasing clover proportion resulted in linear effects for all milk composition parameters for both red clover and white clover. Total daily fat production was unaffected of red clover proportion, whereas white clover resulted in a quadratic effect, with the highest daily fat production on the WC-LPR treatment. The LPR increased the milk fat concentration (47.0 
GRASS AND CLOVER SILAGE FOR MILK PRODUCTION

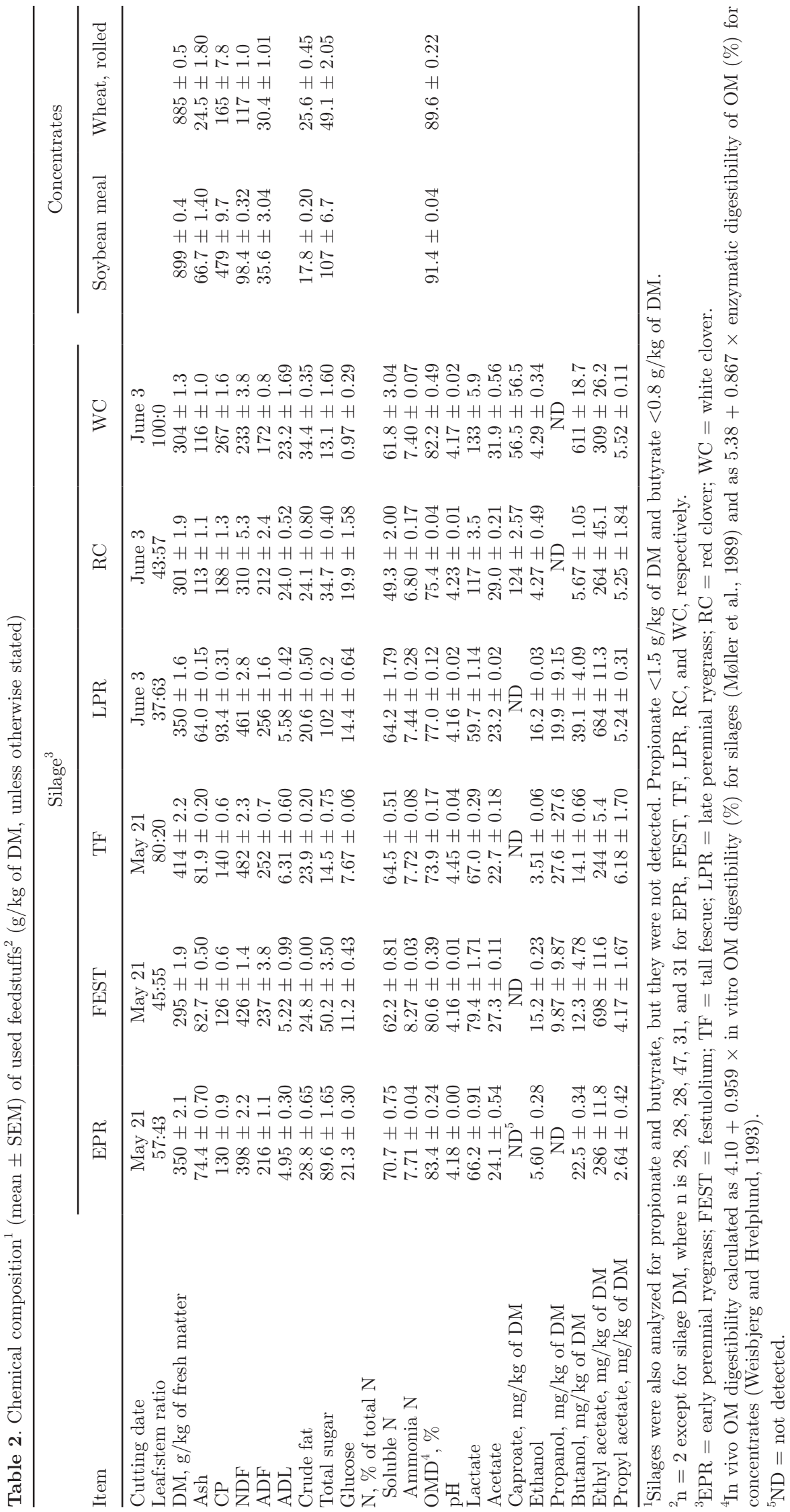


vs. $44.6 \mathrm{~g} / \mathrm{kg} ; P<0.05)$ but reduced the milk protein concentration (35.7 vs. $36.8 \mathrm{~g} / \mathrm{kg} ; P<0.05)$ compared with EPR, whereas FEST and TF did not differ from LPR. None of the grass treatments differed in milk lactose concentration. The 4 grass treatments resulted in similar ECM per kilogram of DMI, but the energy output in milk related to energy intake was lower for the EPR treatment than for the other grass treatments and kilograms of ECM per kilogram OM digested was lower for EPR than for FEST. Increasing the red clover proportion linearly decreased kilograms of ECM per kilogram of DMI, whereas white clover proportion did not affect the ECM production per kilogram of DMI. The energy output in milk related to energy intake did not differ between red clover and white clover.

\section{Feces}

Fecal DM concentration was higher when cows were fed clover than grass (109 vs. $91 \mathrm{~g} / \mathrm{kg}$ of fresh matter; $P<0.01$ ), and red clover resulted in a higher fecal DM concentration than white clover (109 vs. 100 $\mathrm{g} / \mathrm{kg}$ of fresh matter; $P<0.01$; Table 5). Both red clover and white clover increased fecal DM concentration linearly. Feces texture for WC-LPR and WC was more liquid than for all grass treatments, even though fecal DM concentration was similar or higher. The relationship between fecal DM concentration and feces texture within treatment (Figure 1) was positive for all treatments, but the WC-LPR and WC treatments displaced the lines parallel to the left, giving more liquid feces even though DM concentrations were comparable with the other treatments. The chemical composition of feces reflected the chemical composition of the TMR, as feces from cows fed clover had a higher concentration of ash and $\mathrm{CP}$ and a lower concentration of NDF.

\section{Total-Tract Digestibility}

The apparent total-tract digestibility of DM, OM, $\mathrm{NDF}$, and ADF was higher for EPR than for FEST, TF, and LPR, which did not differ (Table 5). The FEST treatment resulted in a lower apparent totaltract $\mathrm{CP}$ digestibility than the other grass treatments, whereas the $\mathrm{WC}$ treatment resulted in a higher $\mathrm{CP}$ digestibility than all other treatments. Inclusion of red clover reduced DM, OM, and ADF digestibility linearly, whereas we observed a tendency for a quadratic decrease for NDF digestibility, as NDF digestibility for $\mathrm{RC}$ was lower than for RC-LPR and LPR (60.7 vs. $68.2-70.8 \%$; Table 5). Inclusion of white clover did not affect DM, OM, NDF, or ADF digestibility. The linear and quadratic effects of clover proportion on CP digestibility were probably affected by urea addition to LPR, and therefore will not be examined further.

Table 3. Carbohydrate fractions, NDF, and CP rumen degradation parameters, and disappearance of CP from mobile bags for used silages (n $=1)$

\begin{tabular}{|c|c|c|c|c|c|c|}
\hline Item & \multicolumn{6}{|c|}{ Silage $^{1}$} \\
\hline $\mathrm{WSC}^{2} \mathrm{~g} / \mathrm{kg}$ of DM & 130 & 84.2 & 42.8 & 127 & 71.7 & 28.4 \\
\hline NDSF ethanol, ${ }^{3} \mathrm{~g} / \mathrm{kg}$ of DM & 97.8 & 105 & 83.3 & 120 & 156 & 162 \\
\hline NDSF water, ${ }^{4} \mathrm{~g} / \mathrm{kg}$ of DM & 87.9 & 90.5 & 79.6 & 95.0 & 132 & 142 \\
\hline $\mathrm{iNDF},{ }^{5} \mathrm{~g} / \mathrm{kg}$ of NDF & 77.4 & 101 & 103 & 119 & 236 & 182 \\
\hline Lag time, $\mathrm{h}$ & 1.37 & 1.24 & 1.22 & 1.72 & 1.18 & 1.99 \\
\hline \multicolumn{7}{|l|}{$\mathrm{CP}$ rumen degradation } \\
\hline Particle loss, $\mathrm{g} / \mathrm{kg}$ of $\mathrm{CP}$ & 81.0 & 96.9 & 101 & 102 & 87.0 & 91.1 \\
\hline $\mathrm{a},{ }^{8} \mathrm{~g} / \mathrm{kg}$ of $\mathrm{CP}$ & 686 & 604 & 611 & 631 & 482 & 598 \\
\hline $\mathrm{b}, \mathrm{g} / \mathrm{kg}$ of $\mathrm{CP}$ & 256 & 327 & 315 & 258 & 477 & 372 \\
\hline $\mathrm{c}, \% / \mathrm{h}$ & 6.11 & 6.23 & 6.59 & 5.18 & 14.4 & 13.4 \\
\hline
\end{tabular}

${ }^{1} \mathrm{EPR}=$ early perennial ryegrass; FEST $=$ festulolium; $\mathrm{TF}=$ tall fescue; $\mathrm{LPR}=$ late perennial ryegrass; $\mathrm{RC}=$ red clover; $\mathrm{WC}=$ white clover.

${ }^{2}$ Water-soluble carbohydrates.

${ }^{3}$ Neutral detergent soluble fiber determined using ethanol as solvent.

${ }^{4}$ Neutral detergent soluble fiber determined using water as solvent.

${ }^{5}$ Indigestible NDF determined by $288 \mathrm{~h}$ of in situ incubation.

${ }^{6}$ Insoluble, but rumen-degradable fraction.

${ }^{7}$ Fractional rate of degradation of fraction $b$.

${ }^{8}$ Rumen-soluble fraction. 
GRASS AND CLOVER SILAGE FOR MILK PRODUCTION

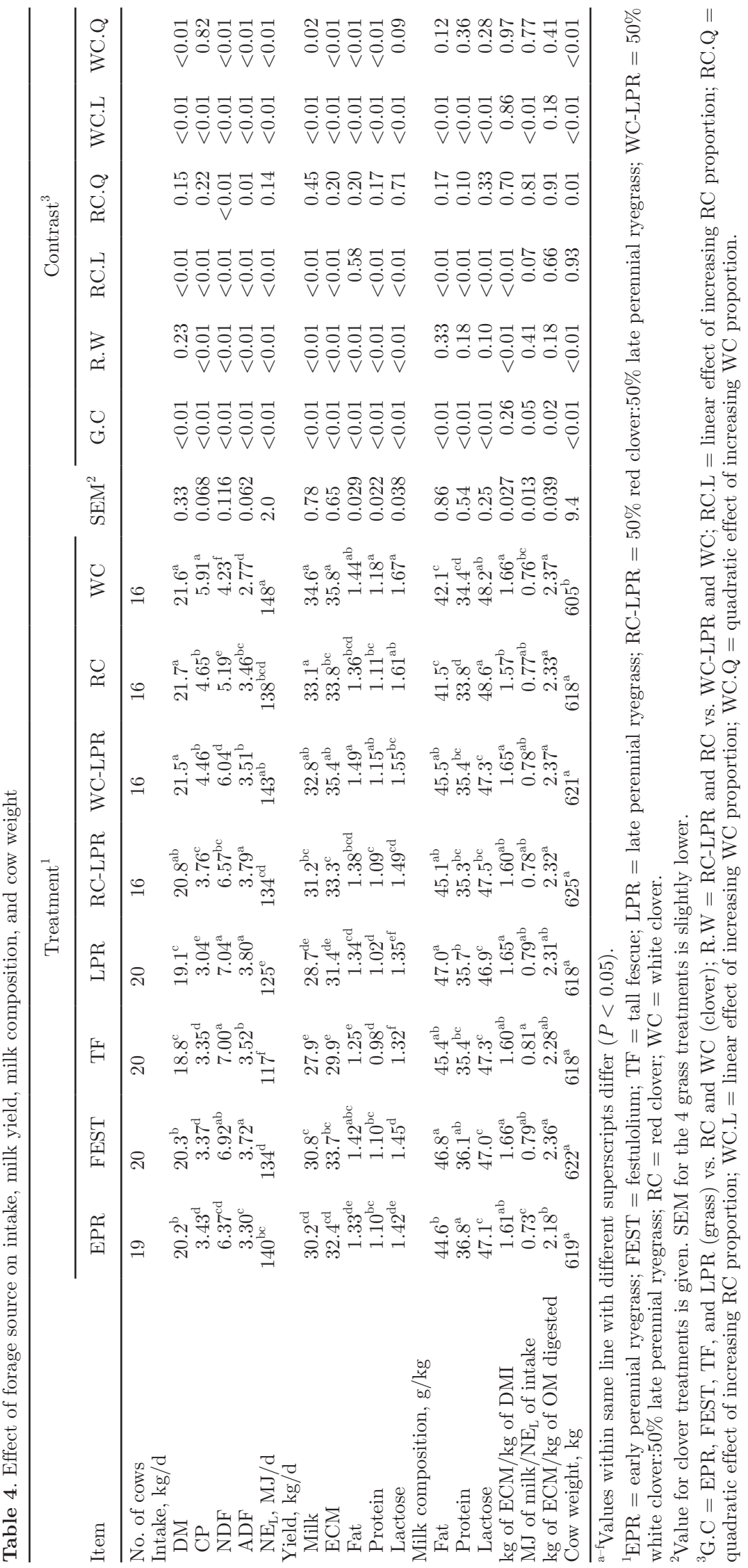


JOHANSEN ET AL.

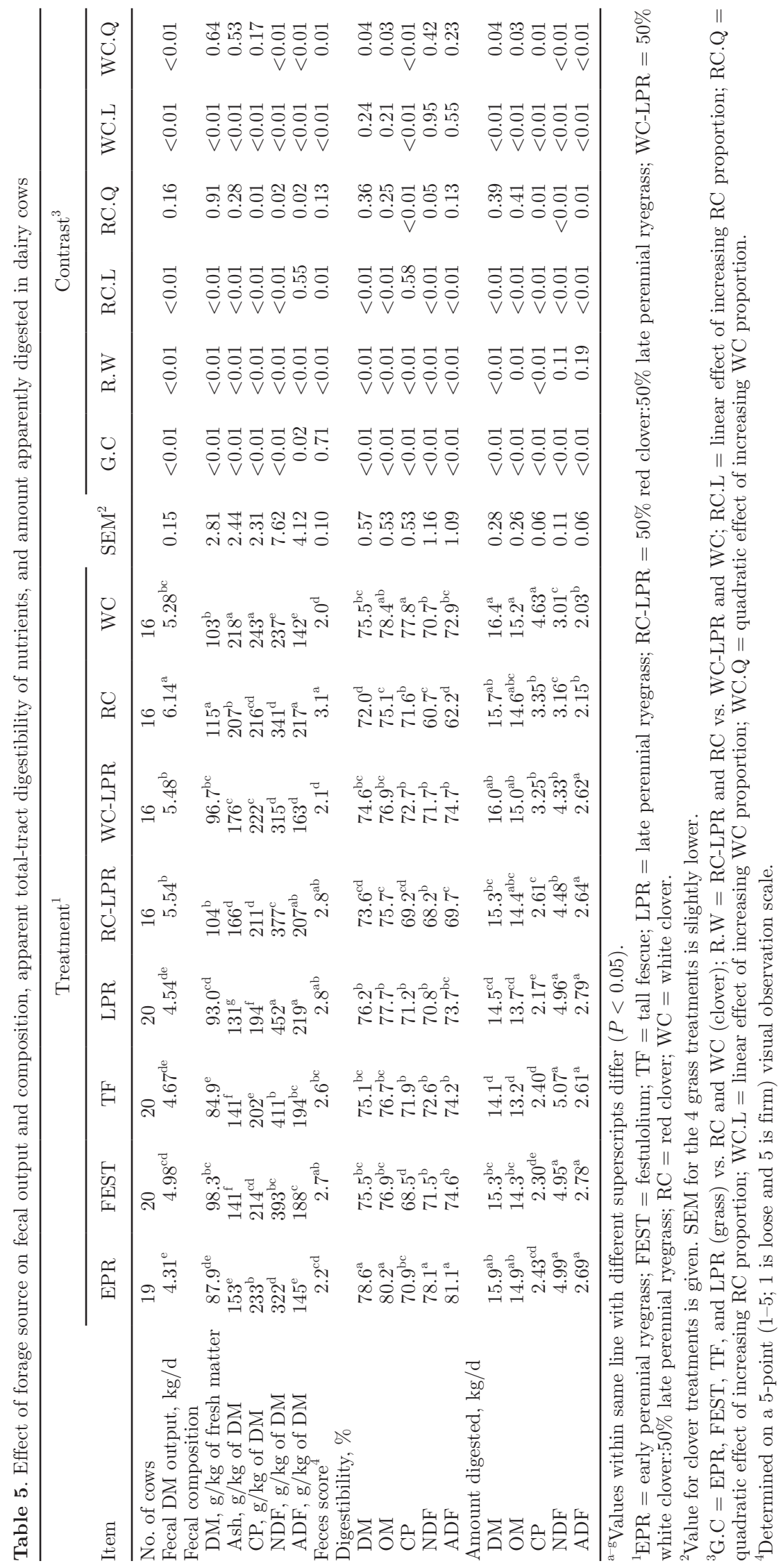




\section{Water Intake and Eating Behavior}

Water intake through feed was dependent on TMR DM concentration, which also affected free water intake (Table 6). Total water intake varied from 101 to 110 $\mathrm{L} / \mathrm{d}$ on the grass treatments, which was lower than total water intake on the clover treatments (114-128 $\mathrm{L} / \mathrm{d}$ ). White clover resulted in higher total water intake, increased duration of total drinking time and of each drinking bout, more drinking bouts, and reduced drinking rate compared with red clover. Increased clover proportion resulted in a linear increase in total water intake, drinking duration, and drinking bouts for both red clover and white clover. Water intake per drinking bout varied from 11.1 to $12.8 \mathrm{~L}$, was larger for $\mathrm{TF}$ than for FEST and RC, and was not affected by clover proportion. The drinking bout duration for WC was longer than for all other treatments (2.81 vs. 1.91-2.28 min; $P<0.05$ ), which also reduced drinking rate, as water intake per bout on WC did not differ from the other treatments.

Cows fed the WC diet spent 0.9 to $1.4 \mathrm{~h}$ less per day at the feeding through than cows on the other treatments $(P<0.05$; Table 6$)$. Feeding with LPR compared with EPR increased eating duration by $0.5 \mathrm{~h} / \mathrm{d}$ but reduced the number of meals from 9.5 to 8.1/d. Eating rate was higher for EPR and FEST than for TF and LPR ( 80.5 and 81.1 vs. 70.3 and $68.2 \mathrm{~g}$ of $\mathrm{DM} / \mathrm{min}$ ), but meal size did not differ between grass treatments. Both red clover and white clover proportion decreased the total eating time and meal duration linearly, but linearly increased the number of meals and eating rate. Red clover proportion did not affect meal size, but white clover proportion resulted in a quadratic effect, as meal size for LPR and WC-LPR did not differ but WC reduced meal size by $0.54 \mathrm{~kg}$ of DM.

\section{DISCUSSION}

\section{Silages}

Both cuts of perennial ryegrass achieved exactly the planned DM concentration of $350 \mathrm{~g} / \mathrm{kg}$. The higher leaf-to-stem ratio for tall fescue compared with early perennial ryegrass probably speeded up the drying process, resulting in a higher DM concentration as opposed to festulolium. The achieved DM concentrations for the clover silages were 301 and $304 \mathrm{~g} / \mathrm{kg}$, as we assessed the risk for loosing leaf material to be too high if wilting continued to a higher DM concentration. All 6 silages were well preserved, as all reached a low $\mathrm{pH}$, with lactate as the most dominating fermentation product without any detectable amount of butyrate (McDonald et al., 1991). Legumes have a higher buffer capacity than grasses (McDonald and Henderson, 1962), resulting in a higher amount of lactate needed to reach a stable $\mathrm{pH}$, which also was seen in our red and white clover silages. Late perennial ryegrass silage had higher NDF, ADF, ADL, NDSF, and iNDF concentrations and a lower leaf-to-stem ratio, CP concentration, and OMD than early perennial ryegrass silage due to the increased maturity, which is consistent with other studies (Kuoppala et al., 2008; Alstrup et al., 2016). In the grass silages, the low ADL concentrations resulting in high iNDF-to-ADL ratios (6.2-9.8) were in contrast to earlier reported iNDF-to-ADL ratios for grass silages of 2.3 to 3.4 (Krämer et al., 2012). The difference might be due to different methodologies used to determine

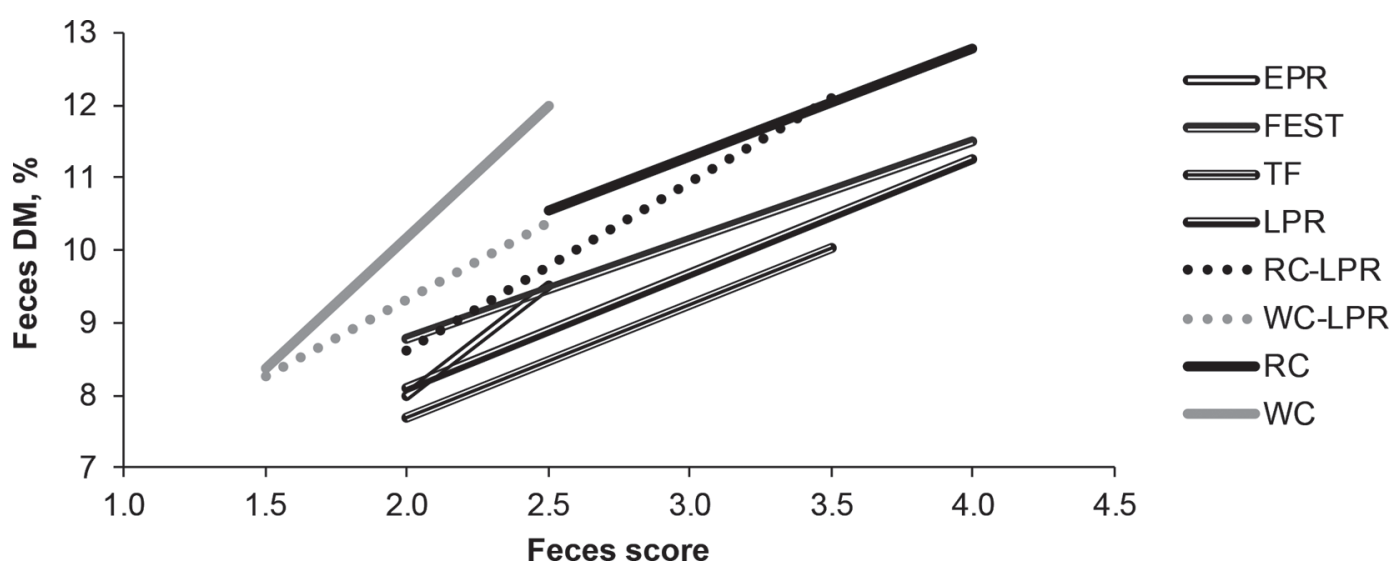

Figure 1. Fecal DM concentration as a function of feces score determined on a 5-point (1-5; 1 is loose and 5 is firm) visual observation scale for dairy cows fed a TMR based on different forage silages $(\mathrm{EPR}=$ early perennial ryegrass; FEST $=$ festulolium; TF $=$ tall fescue; LPR $=$ late perennial ryegrass; $\mathrm{RC}-\mathrm{LPR}=50 \%$ red clover $: 50 \%$ late perennial ryegrass; WC-LPR $=50 \%$ white clover:50\% late perennial ryegrass; $\mathrm{RC}=$ red clover; $\mathrm{WC}=$ white clover). 


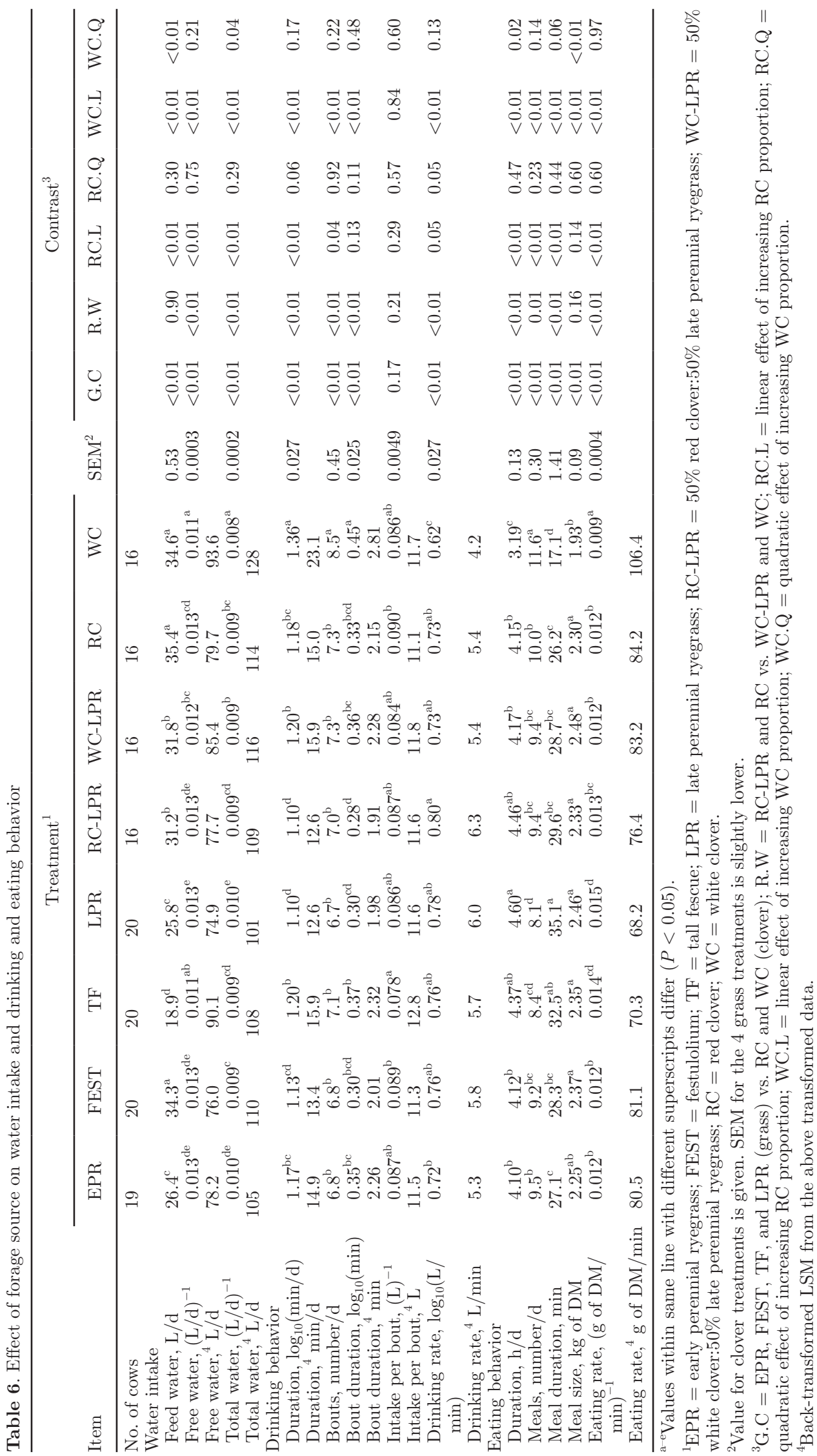


ADL, as the Ankom procedure was used in our study. Postponing harvest of perennial ryegrass $13 \mathrm{~d}$ did not reduce OMD to the level of tall fescue silage, which was the silage with the highest NDF concentration and lowest OMD. Based on the leaf-to-stem ratio, which was very high in tall fescue, this was not expected, as cell wall concentrations normally are lower in leaves than in stems (Wilson, 1994; Buxton and Redfearn, 1997). Leaves of tall fescue have a higher number of sclerenchyma bundles with a higher average area compared with perennial ryegrass, and each single fiber is longer and broader (King et al., 2014). This can probably explain the lower OMD of tall fescue silage than of perennial ryegrass silage. The higher concentration of NDSF demonstrated that legumes contain more pectin substances than grasses (Wilson, 1994).

Red clover silage had a lower concentration of soluble $\mathrm{N}$ and ammonia $\mathrm{N}$ as proportion of total $\mathrm{N}$ compared with the other silages, which may be related to the presence of polyphenol oxidases in red clover (Lee, 2014), resulting in a larger insoluble, but rumen-degradable, protein fraction. Broderick and Albrecht (1997) demonstrated a lower rumen degradation rate of protein in red clover than in white clover, but in our study the fractional rate of protein degradation was similar for white clover and red clover, which was substantially higher than for the grass species. However, the ruminal protein degradation rate in red clover can vary from 7.5 to $35.5 \% / \mathrm{h}$ depending on growth stage and conservation method (Aufrère et al., 2002). The fractional rate of rumen NDF degradation for red clover silage was comparable to values reported by Hoffman et al. (1997), similar to the degradation rate of NDF for white clover silage and higher than that of the grass silages. Generally, legumes have a higher rate of rumen NDF degradation than grasses, but it is highly dependent on maturity stage (Hoffman et al., 1993).

\section{Feed Intake}

As shown in previous studies (Steinshamn, 2010; Johansen et al., 2017), our study confirmed that DMI is higher in cows fed legumes compared with cows fed grasses. The quadratic effect of white clover proportion on DMI and the lower BW in the $\mathrm{WC}$ treatment compared with the other treatments indicated that rumen fill probably did not restrict DMI on the WC treatment, but that DMI probably instead was regulated physiologically (Mertens, 1994). Dewhurst et al. (2003a) and Bertilsson and Murphy (2003) weighed rumen content and found that cows fed white clover had 18 to 20 and $16.5 \mathrm{~kg}$ less material in the rumen, respectively, compared with cows fed grass, red clover, or grass-clover mixes. Thereby, a lower rumen fill, and not loss of body mass, was most probably causing the lower BW on the WC treatment in our study. A notable and immediate drop in BW when cows shifted to WC and RC (data not shown) also supported this. After the drop, both groups increased BW during the first days in the period because of increasing DMI. However, cows on the RC treatment reached the same BW as cows on grass treatments in the end of the period indicating rumen fill to be the same, whereas cows on the WC treatment did not reach the same BW as cows on the other treatments. The DMI was stable for both RC and WC in the last week of the period; therefore, compared with the other treatments, DMI on the WC treatment was not as high as expected based on silage OMD, probably because of a different regulation of DMI. The same was applicable for milk production, which reflected DMI; however, cows on the WC treatment produced the expected amount of milk based on the amount of $\mathrm{OM}$ digested, which is discussed further herein.

In the grass treatments, TF and LPR resulted in a lower DMI compared with EPR and FEST, which may be related to silage OMD. Both FEST and EPR resulted in a similar DMI despite the fact that early perennial ryegrass silage had a higher OMD and a lower concentration of NDF than festulolium silage; therefore, EPR was expected to result in a higher DMI than FEST. To some extent, this might indicate metabolic intake regulation for EPR, such as for WC.

\section{Milk Yield and Milk Composition}

The higher milk and ECM yield for cows fed clover compared with cows fed grass, as well as the higher milk and ECM yield for cows fed white clover compared with cows fed red clover, corresponded with earlier findings (Steinshamn, 2010; Johansen et al., 2017). We did not detect differences in milk composition between cows fed red clover and white clover, but increasing the clover proportion resulted in a linear decrease in fat and protein concentrations and a linear increase in lactose concentration. Moorby et al. (2009) observed a linear decrease in fat and protein concentrations without any differences in lactose concentration, whereas Halmemies-Beauchet-Filleau et al. (2014) observed a linear increase in lactose concentration but no effect on fat concentration when increasing the red clover proportion in the diet. Vanhatalo et al. (2009) reported the same effect on milk fat, protein, and lactose concentrations as observed in our study when increasing the red clover proportion. Lactose is the main osmotic regulator in milk, and thereby the most important factor determining milk yield (Linn, 1988). In our study, lactose production per day increased significantly when increasing the clover proportion, resulting in a higher 
milk yield. The higher milk production can probably explain the increased lactose concentration, because of a higher intramammary pressure, which increases the lactose concentration (Lollivier et al., 2002). However, Halmemies-Beauchet-Filleau et al. (2014) did not detect any differences in milk yield but reported lactose concentrations of 48.2 and $47.3 \mathrm{~g} / \mathrm{kg}$ for cows fed red clover and grass silage, respectively, which is very similar to the lactose concentrations observed in our study.

The increase in daily milk protein production when increasing the clover proportion was probably caused by an increase in $\mathrm{NE}_{\mathrm{L}}$ intake (Linn, 1988). However, lactose production increased even more; thus, the observed changes in protein concentration in our study, when increasing clover proportion, most probably were caused by a dilution of the protein. However, a meta-analysis (Johansen et al., 2017) reported a lower milk protein concentration when cows were fed red clover compared with grasses and white clover, which could be caused by complexing of polyphenol oxidases with plant proteins, protecting proteins from degradation in the rumen and reducing bioavailability of sulfur-containing AA (Lee, 2014). However, our in situ-determined rumen protein degradation rate (Table 3 ) did not differ between white clover and red clover; thus, protein complexes formed by polyphenol oxidases were presumably not responsible for the reduced milk protein concentration when feeding red clover in our study, as similar milk protein concentrations were observed for red clover and white clover.

The decrease in milk fat concentration when increasing clover proportion may be due to changed molar VFA proportions in the rumen when feeding clover compared with grass, as the milk fat concentration is positively related to acetic and butyric acids proportion and negatively related to the propionic acid proportion (Linn, 1988). Fiber degradation stimulates the production of acetic and butyric acid and, according to Mertens (1985), an NDF concentration of $280 \mathrm{~g} / \mathrm{kg}$ and an ADF concentration of $180 \mathrm{~g} / \mathrm{kg}$ in the diet are needed as a minimum to maximize milk production and fat concentration. In our study, fiber concentrations in the RC and WC diets were below these limits, the RC-LPR and WC-LPR diets were close to the limits, and the LPR diet was above the limit (Table 1). This probably can explain the linear decrease in milk fat concentration when the clover proportion is increased. Even though not significant, the cows produced numerically more fat per day when fed RC-LPR compared with RC and LPR and when fed WC-LPR compared with WC and LPR. Vanhatalo et al. (2009) observed a decrease in milk fat concentration and a reduced rumen molar proportion of butyric acid when increasing the red clover proportion. Likewise, Halmemies-Beauchet-Filleau et al. (2013) re- ported a reduced ratio of rumen acetate and butyrate to propionate when increasing the red clover proportion. The reduced milk fat concentration when increasing the clover proportion could also be caused by an increased concentration of milk MUFA and PUFA when cows were fed clover compared with grass (Dewhurst et al., 2003b; Vanhatalo et al., 2007), as these can have an inhibitory effect on the de novo fatty acid synthesis in the mammary gland (Bauman and Griinari, 2003). An increase in milk MUFA and PUFA when feeding clover compared with grass is probably caused by a lower rumen biohydrogenation of polyunsaturated C18 fatty acids (Lejonklev et al., 2013).

The increase in milk fat concentration and decrease in milk protein concentration when the harvest of perennial ryegrass was postponed was in contrast to Vanhatalo et al. (2009), who did not observe any differences in milk composition when grass and red clover of different maturity stages were fed to dairy cows. However, the responses were in agreement with the aforementioned increases in milk protein production due to increased $\mathrm{NE}_{\mathrm{L}}$ intake and increased milk fat concentration due to higher NDF and ADF concentrations in the diet. Nevertheless, a decrease in milk yield counterbalanced the increase in milk fat concentration, whereby daily milk fat production was similar for EPR and LPR. For the grass treatments, FEST resulted in the highest milk fat production per day, which cannot be explained by the NDF and ADF concentrations in the diet.

\section{Relation Between OMD and Milk Production}

The early perennial ryegrass silage had the highest OMD of the grass silages, but the EPR treatment did not result in the highest milk production. A high passage rate could cause an inefficient digestion of the nutrients, but the total-tract digestibility of DM, OM, $\mathrm{NDF}$, and ADF were higher for EPR than the other grass treatments; therefore, a higher passage rate was probably not the cause of the lower than expected milk production. Figure 2a relates ECM to the amount of OM digested in the gastrointestinal tract. The correlation between ECM and the amount of OM digested was generally high $\left(R^{2}=0.78\right)$ across the 8 treatments, but without the EPR treatment coefficient of determination increased to 0.98. Related to the amount of $\mathrm{OM}$ digested, the cows produced $2.6 \mathrm{~kg}$ of ECM less than expected on the EPR treatment compared with the production on the other treatments. An explanation could be that the energy concentration in the digested OM is lower on the EPR treatment than on the other treatments, but nothing in the chemical composition of the silages (Table 2) can explain such a difference and the calculated $\mathrm{NE}_{\mathrm{L}}$ intake (Table 4) was higher 
for EPR than for the other grass treatments. Similarly, in a study by Randby et al. (2012), cows fed a very early harvested, highly digestible grass-clover silage did not produce the milk yield expected from the chemical composition compared with grass-clover silages harvested at later stages of crop maturity with lower OM digestibility. In our study, similar amounts of OM were digested per day on EPR, WC-LPR, and WC; thus, it cannot be the high amount of digested OM that explains the lower utilization of digested OM to milk production on EPR. Cows fed WC digested twice as much CP, but digested $40 \%$ less NDF compared with cows fed grass (Table 5); however, cows fed WC produced the expected amount of milk based on the amount of total OM digested compared with the other treatments. Secretion of surplus nitrogen via urea is an energy-demanding process, and therefore lower energy efficiency could have been expected for cows fed WC. However, Alstrup et al. (2016) reported no negative effects on milk production in dairy cows fed diets with $23.1 \%$ CP of DM, even though large amounts of urea were secreted in milk. The efficiency of protein utilization was similar between grass treatments $(31,32,29$, and $33 \%$ for EPR, FEST, TF, and LPR, respectively) and was lower in the clover treatments than in the grass treatments, but across treatments the efficiency of protein utilization was highly correlated with the TMR CP level. Therefore, the higher proportion of soluble $\mathrm{N}$ in early perennial ryegrass silage compared with the other silages cannot explain the lower than expected milk production. Moreover, BW gain cannot explain the lower than expected milk production in cows fed EPR, neither in our study nor in the study by Randby et al. (2012).

In Figure 2b, ECM is related to silage OMD, and the treatments FEST, TF, and LPR represent a straight line indicating that silage OMD up to at least $80.6 \%$ can explain the variation in ECM between different grass species; 1 unit increase in silage OMD increased ECM with $0.6 \mathrm{~kg} / \mathrm{d}$. Including $50 \%$ clover in the diet increased ECM with $2.3 \mathrm{~kg} / \mathrm{d}$ compared with the pure grass diets when silage OMD was comparable, independently of clover species, and change in silage OMD resulted in the same response in ECM as for the grass treatments. We expected that feeding $100 \%$ clover would increase ECM further and give the same response to changes in silage OMD if rumen fill regulates the intake. However, this was probably not the case for $\mathrm{WC}$, as previously discussed; thus, our data cannot substantiate this. If rumen fill regulates intake, our data indicated that the response in ECM was higher when increasing clover proportion from 0 to $50 \%$ than from 50 to $100 \%$, as RC-LPR increased ECM with $1.9 \mathrm{~kg} / \mathrm{d}$ compared with LPR whereas RC only increased ECM with $0.5 \mathrm{~kg} / \mathrm{d}$ compared with RC-LPR. Figure 2b indicates an optimum for silage OMD in relation to ECM production, and the relationship between ECM and silage OMD can probably be quadratic with separate lines for grass- and clover-containing diets, respectively. Cows on EPR and $\mathrm{WC}$, which were the treatments including the silages with the highest OMD, responded differently compared with cows on the other treatments, as already discussed. Although the optimum could not be determined exactly, our data indicates that the optimum for silage OMD is within the range 79 to $82 \%$.

Figure 2c relates the apparent total-tract OM digestibility to silage OMD. For the treatments with a silage OMD of 76 to $77 \%$ we noted high agreement to the apparent total-tract digestibility, whereas treatments with a higher silage OMD were below the identity line and vice versa. Values reported by Kuoppala et al. (2009) indicate similar tendencies when comparing silage OM digestibility obtained in vivo in sheep fed at maintenance and total-tract $\mathrm{OM}$ digestibility in producing dairy cows fed silage ad libitum and concentrate. Compared with the other grass treatments, total-tract OM digestibility for FEST differed more from silage OMD, and the deviation was comparable to the deviations obtained for the 2 treatments containing white clover. When comparing ECM to apparent total-tract OM digestibility (Figure 2d), FEST is located closer to the 4 clover treatments than to the other grass treatments. The festulolium silage had an iNDF concentration comparable to the tall fescue silage, but the fractional rate of NDF degradation was $5.12 \% / \mathrm{h}$ for festulolium silage compared with $4.06 \% / \mathrm{h}$ for tall fescue silage (Table 3 ). Therefore, the shape of the NDF degradation curve for festulolium silage differed from the other 3 grass silages, which were more or less similar in shape. Instead, the shape of the NDF degradation curve for festulolium silage was more toward the shape of the 2 clover silages, which were also similar in shape. Based on the total-tract NDF digestibility and the NDF degradation curves for the silages, the fractional rate of passage for NDF could be calculated as $0.83,1.24,0.96,0.95,1.61$, and $1.09 \% / \mathrm{h}$ in EPR, FEST, TF, LPR, RC, and WC, respectively. This indicates that the fiber in festulolium behaves more like fiber in legumes when fed to dairy cows, but this is not reflected in silage OMD. The explanation for this needs to be studied further.

\section{CP Digestibility and Feces}

The total-tract CP digestibility reflected the disappearance of CP from mobile bags, as FEST resulted in a lower total-tract $\mathrm{CP}$ digestibility than EPR and $\mathrm{TF}$ and white clover resulted in a higher total-tract CP digestibility than red clover. Generally, a higher 

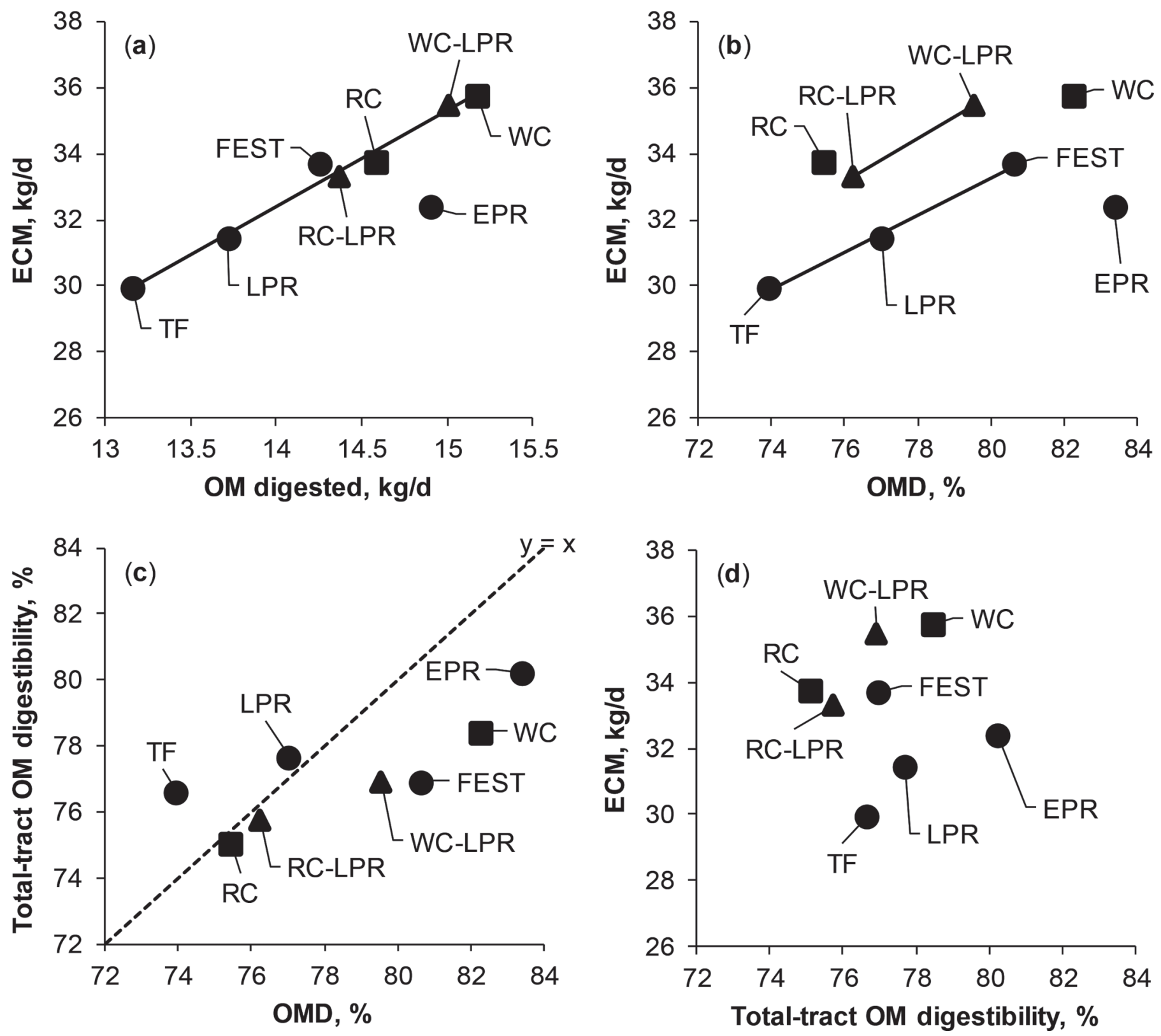

Figure 2. Relationship between (a) ECM and amount of OM digested in the gastrointestinal tract with the regression line $\left(\mathrm{R}^{2}=0.98\right)$ across treatments without EPR; (b) ECM and silage in vivo OM digestibility (OMD) calculated as $4.10+0.959 \times$ in vitro OM digestibility (Møller et al., 1989); (c) total-tract OM digestibility and OMD; and (d) ECM and total-tract OM digestibility for dairy cows fed TMR based on different forage silages $(\mathrm{EPR}=$ early perennial ryegrass; $\mathrm{FEST}=$ festulolium; $\mathrm{TF}=$ tall fescue; $\mathrm{LPR}=$ late perennial ryegrass; $\mathrm{RC}-\mathrm{LPR}=50 \%$ red clover: $50 \%$ late perennial ryegrass; WC-LPR $=50 \%$ white clover: $50 \%$ late perennial ryegrass; $\mathrm{RC}=$ red clover; WC $=$ white clover)

feed $\mathrm{CP}$ concentration increased $\mathrm{CP}$ digestibility, both when comparing silage $\mathrm{CP}$ concentration with disappearance of $\mathrm{CP}$ from mobile bags and when comparing TMR CP concentration with total-tract CP digestibility. However, total-tract $\mathrm{CP}$ digestibility was lower for FEST and RC-LPR than for EPR, TF, and LPR even though the TMR CP concentration was similar. The lower total-tract CP digestibility for red clover com- pared with grass and white clover is in accordance with Dewhurst et al. (2003b).

Despite similar fecal DM concentrations, feces scores were lower for WC-LPR and WC compared with the other treatments. The missing correlation between fecal DM concentration and fecal consistency has also been observed by Ireland-Perry and Stallings (1993) in dairy cows fed diets differing in ADF concentration. Mgbea- 
huruike et al. (2016) reported a positive correlation between diet NDF concentration and fecal consistency; however, differences in dietary or fecal concentrations of major nutrients could not explain the differences in feces scores observed in our study. Different plant fibers have different water binding capacity (Chen et al., 1984), indicating that the fiber fraction in white clover silage differs in water binding capacity compared with the fiber fraction in the other silages resulting in the more liquid feces.

\section{Drinking and Eating Behavior}

Daily free water intakes in our study correspond well to previously published data for lactating cows [e.g., 89.5 L/d (Dado and Allen, 1994) and 83.6 L/d (Cardot et al., 2008)]. Water intake is affected by many factors, including DMI, milk yield, feed DM concentration, weather conditions (temperature and rainfall), and $\mathrm{CP}$ and potassium intakes (Cardot et al., 2008; Kume et al., 2010). The higher water intake when feeding clover compared with grass in our study was probably a combination of higher DMI, higher milk yield, and higher $\mathrm{CP}$ intake. White clover and red clover did not differ in DMI; thus, presumably it was the difference in milk yield and $\mathrm{CP}$ intake, which caused the difference in water intake between red clover and white clover.

In our study, the average number of drinking bouts of 7.2 corresponds well to 7.3 drinking bouts/d as reported by Cardot et al. (2008). The drinking behavior for cows on WC was notably different from the other treatments, which did not differ substantially. The water intake per drinking bout in $\mathrm{WC}$ was similar to the other treatments, resulting in an increased number of drinking bouts per day to increase free water intake. However, the duration of each drinking bout was longer, making the drinking rate slower for cows offered WC, resulting in total drinking duration to be $60 \%$ higher for cows fed WC compared with the other treatments. The drinking rate is affected by water flow rate to the water-bowl and social rank (Andersson et al., 1984), but these factors cannot explain the difference between treatments observed in our study, as the cows drank from a drinking trough with a free water surface that was filled up between visits and cows stayed in the same group throughout the experiment. Whether rumen fill and rumen NDF concentration affect drinking rate is unknown, but these are factors that we expect to have had an influence on the drinking behavior in the WC treatment. The longer drinking duration for cows fed WC could also be an indirect effect of the lesser time spent eating.

Eating rate is negatively correlated with NDF and ADF concentrations in the diet (McLeod and Smith,
1989), which can explain the higher eating rate for white clover than for red clover and the linear increase in eating rate when increasing the clover proportion. The increased eating rate reduced total eating duration per day, even though total DMI was higher when increasing the clover proportion and when comparing EPR and LPR. Clover proportion or grass species did not affect meal size; thus, an increased eating rate reduced meal duration. Furthermore, the unchanged meal size increased meals per day when total DMI was higher, which is in contrast to findings by Beauchemin et al. (2002) and Dewhurst et al. (2003b), where similar numbers of larger meals were associated with increased intake. However, cows fed the WC diet on average consumed $0.43 \mathrm{~kg}$ of DM less per meal than cows fed the other diets, resulting in more meals in WC than WCLPR, even though DMI did not differ. When rumen fill regulates intake, distension of receptors in the rumen wall stimulates the cow to end a meal (Allen, 2000). On the contrary, when feeding high levels of concentrate or high-quality silages, the high production of VFA over a short period stimulates ruminal epithelial receptors resulting in meal cessation, which reduces meal duration and meal size (Allen, 2000). As white clover silage presumably has a rapid rate of ruminal fermentation, the stimulation of ruminal epithelial receptors can probably explain the smaller meal size and the shorter meal duration for cows fed WC.

\section{Applications}

Our findings indicated that production responses within both grass and clover species could be predicted based on in vitro OMD analyses of the silage. This is a useful tool for farmers regarding optimization of forage and milk production. Normally, grass and clover are cultivated in mixed swards, but the clover proportion can vary widely due to management and seasonal differences (Søegaard, 2009; Eriksen et al., 2014). Therefore, when evaluating the milk production potential of a grass-clover mixture based on in vitro OMD analyses of the silage, it is important to know the clover proportion, as clover inclusion up to at least 50\% will increase milk production compared with pure grass at the same silage OMD level. To optimize profitability, the farmers should consider not only harvest yield and production costs, but also digestibility and inclusion rate of clover, and hereupon select the species most suitable for local conditions.

\section{CONCLUSIONS}

Differences in ECM in cows fed silages of different grass species could be explained by differences in silage 
OMD; likewise, at comparable silage OMD, inclusion of clover in the diets increased ECM. Cows fed grass silage with a high OMD (83.4\%) did not produce the expected amount of ECM based on the amount of OM actually digested in the gastrointestinal tract. The results indicated that feed intake when feeding pure white clover was regulated physiologically instead of physically and, simultaneously, the eating and drinking behavior differed markedly from what of cows fed the other silages.

\section{ACKNOWLEDGMENTS}

The study formed part of the project "Optimal milk production with grasses and legumes" funded by the Danish Milk Levy Fund (Mælkeafgiftsfonden) and Department of Animal Science, Aarhus University. We thank DLF (Roskilde, Denmark) for providing seeds; the field crew for establishing and managing the fields and ensiling the forages; Mads Pilgaard (Midtjydsk Maskinstation A/S, Brande, Denmark) for wrapping bales; the barn crew for animal care, feeding, and milking; Torkild Nyholm Jacobsen (AU Foulum, Tjele, Denmark) for skillful assistance with sampling; the laboratory technicians for performing the chemical analyses; Mary Beth Hall (US Dairy Forage Research Center, Madison, WI) for hosting the first author (M. Johansen), access to carbohydrate analyses, and useful comments on the manuscript; Jan Pitas (US Dairy Forage Research Center) for assistance with carbohydrate analyses; and Martin Øvli Kristensen (AU Foulum, Tjele, Denmark) for computing $\mathrm{NE}_{\mathrm{L}}$ values.

\section{REFERENCES}

Åkerlind, M., M. R. Weisbjerg, T. Eriksson, R. Thøgersen, P. Udén, B. L. Ólafsson, O. M. Harstad, and H. Volden. 2011. Feed analyses and digestion methods. Pages 41-54 in NorFor-The Nordic Feed Evaluation System. H. Volden, ed. Wageningen Academic Publishers, Wageningen, the Netherlands.

Allen, M. S. 2000. Effects of diet on short-term regulation of feed intake by lactating dairy cattle. J. Dairy Sci. 83:1598-1624. https:// doi.org/10.3168/jds.S0022-0302(00)75030-2.

Alstrup, L., K. Søegaard, and M. R. Weisbjerg. 2016. Effects of maturity and harvest season of grass-clover silage and of forage-toconcentrate ratio on milk production of dairy cows. J. Dairy Sci. 99:328-340. /https://doi.org/10.3168/jds.2015-9802.

Andersson, M., J. Schaar, and H. Wiktorsson. 1984. Effects of drinking water flow rates and social rank on performance and drinking behavior of tied-up dairy cows. Livest. Prod. Sci. 11:599-610. https://doi.org/10.1016/0301-6226(84)90074-5.

ANKOM. 2016. Analytical methods. ANKOM Technology. Accessed Sept, 2016. https://www.ankom.com/analytical-methods-support/ fiber-analyzer-a2000.

Aufrère, J., D. Graviou, and C. Demarquilly. 2002. Protein degradation in the rumen of red clover forage at various stages of growth and conserved as silage or wrapped big bales. Reprod. Nutr. Dev. 42:559-572. https://doi.org/10.1051/rnd:2002041.
Bates, D., M. Mächler, B. Bolker, and S. Walker. 2015. Fitting linear mixed-effects models using lme4. J. Stat. Softw. 67:1-48. /https:// doi.org/10.18637/jss.v067.i01.

Bauman, D. E., and J. M. Griinari. 2003. Nutritional regulation of milk fat synthesis. Annu. Rev. Nutr. 23:203-227. https://doi.org/ 10.1146/annurev.nutr.23.011702.073408.

Beauchemin, K. A., M. Maekawa, and D. A. Christensen. 2002. Effect of diet and parity on meal patterns of lactating dairy cows. Can. J. Anim. Sci. 82:215-223. https://doi.org/10.4141/A01-080.

Bertilsson, J., and M. Murphy. 2003. Effects of feeding clover silages on feed intake, milk production and digestion in dairy cows. Grass Forage Sci. 58:309-322. https://doi.org/10.1046/j.1365-2494.2003 $.00383 . x$

Broderick, G. A., and K. A. Albrecht. 1997. Ruminal in vitro degradation of protein in tannin-free and tannin-containing forage legume species. Crop Sci. 37:1884-1891. https://doi.org/10.2135/ cropsci1997.0011183X003700060037x.

Buxton, D. R., and D. D. Redfearn. 1997. Plant limitations to fiber digestion and utilization. J. Nutr. 127:814S-818S.

Cardot, V., Y. Le Roux, and S. Jurjanz. 2008. Drinking behavior of lactating dairy cows and prediction of their water intake. J. Dairy Sci. 91:2257-2264. https://doi.org/10.3168/jds.2007-0204.

Chen, J. Y., M. Piva, and T. P. Labuza. 1984. Evaluation of water binding capacity (WBC) of food fiber sources. J. Food Sci. 49:5963. https://doi.org/10.1111/j.1365-2621.1984.tb13668.x.

Dado, R. G., and M. S. Allen. 1994. Variation in and relationships among feeding, chewing, and drinking variables for lactating dairy cows. J. Dairy Sci. 77:132-144. https://doi.org/10.3168/jds.S0022 -0302(94)76936-8.

Danish Ministry of Environment and Food. 2014. Bekendtgørelse af lov om dyrefors $\varnothing$ g. LBK nr. 474, May 15, 2014. https://www .retsinformation.dk/eli/lta/2014/474.

Dewhurst, R. J., R. T. Evans, N. D. Scollan, J. M. Moorby, R. J. Merry, and R. J. Wilkins. 2003a. Comparison of grass and legume silages for milk production. 2. In vivo and in sacco evaluations of rumen function. J. Dairy Sci. 86:2612-2621. https://doi.org/10 .3168/jds.S0022-0302(03)73856-9.

Dewhurst, R. J., W. J. Fisher, J. K. S. Tweed, and R. J. Wilkins. 2003b. Comparison of grass and legume silages for milk production. 1. Production responses with different levels of concentrate. J. Dairy Sci. 86:2598-2611. https://doi.org/10.3168/jds.S0022 $-0302(03) 73855-7$.

DuBois, M., K. A. Gilles, J. K. Hamilton, P. A. Rebers, and F. Smith. 1956. Colorimetric method for determination of sugars and related substances. Anal. Chem. 28:350-356. https://doi.org/10.1021/ ac60111a017.

Dürst, B., M. Senn, and W. Langhans. 1993. Eating patterns of lactating dairy cows of three different breeds fed grass ad lib. Physiol. Behav. 54:625-631. https://doi.org/10.1016/0031-9384(93)90069 $-r$.

Eriksen, J., M. Askegaard, and K. Søegaard. 2014. Complementary effects of red clover inclusion in ryegrass-white clover swards for grazing and cutting. Grass Forage Sci. 69:241-250. https://doi .org $/ 10.1111 / \mathrm{gfs} .12025$.

European Community. 2012. First commission directive 71/250/EEC establishing Community methods of analysis for the official control of feedingstuffs, 15 June 1971. http://faolex.fao.org/cgi-bin/faolex .exe?rec_id $=027228 \&$ database $=$ faolex\&search_type $=$ link\&table $=$ result\&lang=eng\&format_name=@ERALL.

Hall, M. B. 2009. Determination of starch, including maltooligosaccharides, in animal feeds: Comparison of methods and a method recommended for AOAC collaborative study. J. AOAC Int. 92:42-49.

Hall, M. B., W. H. Hoover, J. P. Jennings, and T. K. M. Webster. 1999. A method for partitioning neutral detergent-soluble carbohydrates. J. Sci. Food Agric. 79:2079-2086. https://doi.org/10.1002/ (sici)1097-0010(199912)79:15<2079:aid-jsfa502>3.3.co;2-q.

Halmemies-Beauchet-Filleau, A., A. Vanhatalo, V. Toivonen, T. Heikkilä, M. R. F. Lee, and K. J. Shingfield. 2013. Effect of replacing grass silage with red clover silage on ruminal lipid metabolism in lactating cows fed diets containing a 60:40 forage-to-concentrate 
ratio. J. Dairy Sci. 96:5882-5900. https://doi.org/10.3168/jds .2013-6872.

Halmemies-Beauchet-Filleau, A., A. Vanhatalo, V. Toivonen, T. Heikkilä, M. R. F. Lee, and K. J. Shingfield. 2014. Effect of replacing grass silage with red clover silage on nutrient digestion, nitrogen metabolism, and milk fat composition in lactating cows fed diets containing a 60:40 forage-to-concentrate ratio. J. Dairy Sci. 97:3761-3776. https://doi.org/10.3168/jds.2013-7358.

Hansen, B. 1989. Determination of nitrogen as elementary-N, an alternative to Kjeldahl. Acta Agric. Scand. 39:113-118. https://doi .org/10.1080/00015128909438504.

Hoffman, P. C., D. K. Combs, N. M. Brehm, and D. A. Welch. 1997. Performance of lactating dairy cows fed red clover or alfalfa silage. J. Dairy Sci. 80:3308-3315. https://doi.org/10.3168/jds.S0022 -0302(97)76306-9.

Hoffman, P. C., S. J. Sievert, R. D. Shaver, D. A. Welch, and D. K. Combs. 1993. In situ dry matter, protein, and fiber degradation of perennial forages. J. Dairy Sci. 76:2632-2643. https://doi.org/10 .3168/jds.S0022-0302(93)77599-2.

Hvelplund, T., and M. R. Weisbjerg. 2000. In situ techniques for the estimation of protein degradability and postrumen availability. Pages $233-258$ in Forage Evaluation in Ruminant Nutrition. D. I. Givens, E. Owen, R. F. E. Axford, and H. M. Omed, ed. CABI Publishing, CAB International, Wallingford, Oxon, UK.

Hvelplund, T., M. R. Weisbjerg, and L. S. Andersen. 1992. Estimation of the true digestibility of rumen undegraded dietary protein in the small intestine of ruminants by the mobile bag technique. Acta Agric. Scand. A Anim. Sci. 42:34-39. https://doi.org/10.1080/ 09064709209410106.

Ireland-Perry, R. L., and C. C. Stallings. 1993. Fecal consistency as related to dietary composition in lactating Holstein cows. J. Dairy Sci. 76:1074-1082. https://doi.org/10.3168/jds.S0022 -0302(93)77436-6.

Johansen, M., P. Lund, and M. R. Weisbjerg. 2017. Feed intake and milk production in dairy cows fed different grass and legume species-A meta-analysis. Animal https://doi.org/10.1017/ S1751731117001215.

King, C., J. McEniry, M. Richardson, and P. O'Kiely. 2014. Characterization for industrial purposes of the fibre anatomy of perennial ryegrass and tall fescue stem and leaf at three stages in the primary growth. Grass Forage Sci. 69:64-73. https://doi.org/10 $.1111 /$ gfs. 12032

Krämer, M., M. R. Weisbjerg, P. Lund, C. S. Jensen, and M. G. Pedersen. 2012. Estimation of indigestible NDF in forages and concentrates from cell wall composition. Anim. Feed Sci. Technol. 177:40-51. https://doi.org/10.1016/j.anifeedsci.2012.07.027.

Kristensen, N. B., A. Danfær, V. Tetens, and N. Agergaard. 1996. Portal recovery of intraruminally infused short-chain fatty acids in sheep. Acta Agric. Scand. A Anim. Sci. 46:26-38. https://doi.org/ 10.1080/09064709609410921.

Kristensen, N. B., K. H. Sloth, O. Højberg, N. H. Spliid, C. Jensen, and R. Thøgersen. 2010. Effects of microbial inoculants on corn silage fermentation, microbial contents, aerobic stability, and milk production under field conditions. J. Dairy Sci. 93:3764-3774. https://doi.org/10.3168/jds.2010-3136.

Kume, S., K. Nonaka, T. Oshita, and T. Kozakai. 2010. Evaluation of drinking water intake, feed water intake and total water intake in dry and lactating cows fed silages. Livest. Sci. 128:46-51. https:// doi.org/10.1016/j.livsci.2009.10.012.

Kuoppala, K., S. Ahvenjärvi, M. Rinne, and A. Vanhatalo. 2009. Effects of feeding grass or red clover silage cut at two maturity stages in dairy cows. 2. Dry matter intake and cell wall digestion kinetics. J. Dairy Sci. 92:5634-5644. https://doi.org/10.3168/jds.2009 -2250 .

Kuoppala, K., M. Rinne, J. Nousiainen, and P. Huhtanen. 2008. The effect of cutting time of grass silage in primary growth and regrowth and the interactions between silage quality and concentrate level on milk production of dairy cows. Livest. Sci. 116:171-182. https://doi.org/10.1016/j.livsci.2007.10.002.
Lee, M. R. F. 2014. Forage polyphenol oxidase and ruminant livestock nutrition. Front. Plant Sci. 5:694. https://doi.org/10.3389/ fpls.2014.00694.

Lejonklev, J., A. C. Storm, M. K. Larsen, G. Mortensen, and M. R. Weisbjerg. 2013. Differences in rate of ruminal hydrogenation of $\mathrm{C} 18$ fatty acids in clover and ryegrass. Animal 7:1607-1613. https://doi.org/10.1017/S1751731113001286.

Lenth, R. V. 2016. Least-squares means: The R package lsmeans. J. Stat. Softw. 69:1-33. https://doi.org/10.18637/jss.v069.i01.

Linn, J. G. 1988. Factors affecting the composition of milk from dairy cows. Pages 224-241 in Designing Foods: Animal Product Options in the Marketplace. Committee on Technological Options to Improve the Nutritional Attributes of Animal Products, National Research Council, National Academy Press, Washington, DC.

Lollivier, V., J. Guinard-Flament, M. Ollivier-Bousquet, and P. G. Marnet. 2002. Oxytocin and milk removal: Two important sources of variation in milk production and milk quality during and between milkings. Reprod. Nutr. Dev. 42:173-186. https://doi.org/ 10.1051/rnd:2002016.

McDonald, I. 1981. A revised model for the estimation of protein degradability in the rumen. J. Agric. Sci. 96:251-252. https://doi .org $/ 10.1017 /$ S0021859600032081.

McDonald, P., and A. R. Henderson. 1962. Buffering capacity of herbage samples as a factor in ensilage. J. Sci. Food Agric. 13:395-400. https://doi.org/10.1002/jsfa.2740130709.

McDonald, P., A. R. Henderson, and S. J. E. Heron. 1991. The Biochemistry of Silage. 2nd ed. Chalcombe Publication, Bucks, UK.

McLeod, M. N., and B. R. Smith. 1989. Eating and ruminating behavior in cattle given forages differing in fiber content. Anim. Prod. 48:503-511. https://doi.org/10.1017/S0003356100004025.

Mertens, D. R. 1985. Effect of fibre on feed quality for dairy cows. Pages 209-224 in Proceedings of the 46th Minnesota Nutrition Conference and Monsanto Technical Symposium. F. Ehle, J. Ellsworth, and G. Wagner, ed. University of Minnesota Press, Saint Paul, MN.

Mertens, D. R. 1994. Regulation of forage intake. Pages 450-493 in Forage Quality, Evaluation, and Utilization. G. C. Fahey, M. Collins, D. R. Mertens, and L. E. Moser, ed. American Society of Agronomy, Madison, WI. https://doi.org/10.2134/1994.foragequality.c11.

Mertens, D. R. 2002. Gravimetric determination of amylase-treated neutral detergent fiber in feeds with refluxing in beakers or crucibles: Collaborative study. J. AOAC Int. 85:1217-1240.

Mgbeahuruike, A. C., P. Nørgaard, T. Eriksson, M. Nordqvist, and E. Nadeau. 2016. Faecal characteristics and milk production of dairy cows in early-lactation fed diets differing in forage types in commercial herds. Acta Agric. Scand. A Anim. Sci. 66:8-16. https:// doi.org/10.1080/09064702.2016.1193216.

Møller, E., P. E. Andersen, and N. Witt. 1989. En sammenligning af in vitro opløselighed og in vivo fordøjelighed af organisk stof $i$ grovfoder. 13. Beretning fra Fællesudvalget for Statens Planteavls, og Husdyrsbrugsforsøg, Danmark.

Moorby, J. M., M. R. F. Lee, D. R. Davies, E. J. Kim, G. R. Nute, N. M. Ellis, and N. D. Scollan. 2009. Assessment of dietary ratios of red clover and grass silages on milk production and milk quality in dairy cows. J. Dairy Sci. 92:1148-1160. https://doi.org/10.3168/ jds.2008-1771.

Myers, W. D., P. A. Ludden, V. Nayigihugu, and B. W. Hess. 2004 Technical note: A procedure for the preparation and quantitative analysis of samples for titanium dioxide. J. Anim. Sci. 82:179-183.

Ørskov, E. R., and I. McDonald. 1979. The estimation of protein degradability in the rumen from incubation measurements weighted according to rate of passage. J. Agric. Sci. 92:499-503. https://doi .org/10.1017/S0021859600063048.

R Core Team. 2016. R: A Language and Environment for Statistical Computing. R Foundation for Statistical Computing, Vienna, Austria. http://www.R-project.org/.

Randby, Å. T., M. R. Weisbjerg, P. Nørgaard, and B. Heringstad. 2012. Early lactation feed intake and milk yield responses of dairy cows offered grass silages harvested at early maturity stages. J. Dairy Sci. 95:304-317. https://doi.org/10.3168/jds.2011-4454. 
Sjaunja, L. O., L. Baevre, L. Junkkarinen, J. Pedersen, and J. Setälä 1991. A Nordic proposal for an energy corrected milk (ECM) formula. Performance Recording of Animals-State of the Art 1990. EAAP Publication 50:156-157.

Skinner, R. H., and K. J. Moore. 2007. Growth and development of forage plants. Pages 53-65 in Forages, Volume II, The Science of Grassland Agriculture, 6th ed. R. F. Barnes, C. J. Nelson, K. J. Moore, and M. Collins, ed. Blackwell Publishing, Ames, IA.

Søegaard, K. 2009. Nitrogen fertilization of grass/clover swards under cutting or grazing by dairy cows. Acta Agric. Scand. B Soil Plant Sci. 59:139-150. https://doi.org/10.1080/09064710802022911.

Steinshamn, H. 2010. Effect of forage legumes on feed intake, milk production and milk quality-A review. Anim. Sci. Pap. Rep. 28:195-206.

Stoldt, W. 1952. Vorschlag zur Vereinheitlichung der Fettbestimmung in Lebensmitteln. Eur. J. Lipid Sci. Technol. 54:206-207. https:// doi.org/10.1002/lipi.19520540406.

Tilley, J. M. A., and R. A. Terry. 1963. A two-stage technique for the in vitro digestion of forage crops. J. Br. Grassl. Soc. 18:104-111. https://doi.org/10.1111/j.1365-2494.1963.tb00335.x.
Vanhatalo, A., K. Kuoppala, S. Ahvenjärvi, and M. Rinne. 2009. Effects of feeding grass or red clover silage cut at two maturity stages in dairy cows. 1. Nitrogen metabolism and supply of amino acids. J. Dairy Sci. 92:5620-5633. https://doi.org/10.3168/jds.2009-2249.

Vanhatalo, A., K. Kuoppala, V. Toivonen, and K. J. Shingfield. 2007. Effects of forage species and stage of maturity on bovine milk fatty acid composition. Eur. J. Lipid Sci. Technol. 109:856-867. https: // doi.org/10.1002/ejlt.200700023.

Volden, H., and N. I. Nielsen. 2011. Energy and metabolizable protein supply. Pages 81-84 in NorFor-The Nordic Feed Evaluation System. H. Volden, ed. Wageningen Academic Publishers, Wageningen, the Netherlands.

Weisbjerg, M. R., and T. Hvelplund. 1993. Bestemmelse af nettoenergiindhold (FEK) i råvarer og kraftfoderblandinger. Forskningsrapport nr. 3. Statens Husdyrbrugsfors $\varnothing g$, Tjele, Denmark. (In Danish).

Wilson, J. R. 1994. Cell wall characteristics in relation to forage digestion by ruminants. J. Agric. Sci. 122:173-182. https://doi.org/10 $.1017 /$ S0021859600087347. 